The Canadian Journal of Higher Education, Vol. XXIII-2, 1993

La revue canadienne d'enseignement supérieur, Vol. XXIII-2, 1993

\title{
Student Reactions to a Faculty Strike
}

\section{MAUREEN AMOS*, VICTOR H. DAY† \& ELIZABETH POWER $\triangle$}

\begin{abstract}
Following a three week faculty strike at Dalhousie University in 1988, questionnaires were obtained from 187 students concerning how the strike affected their academic work, emotions and opinions of the university. Results were analyzed separately for first year undergraduates, other undergraduates, and graduate or professional school students. There was much individual variability in reactions, but on average the strike had slightly negative academic and emotional effects but substantial negative effects on opinions about the university. Undergraduate students indicated the most academic disruption, and upper year undergraduates indicated the most negative opinions. There was no correlation, however, between degree of personally experienced academic disruption and degree of negative opinion. Another survey two years after the strike indicated the reestablishment of positive opinions. Implications for ameliorating the effects of a faculty strike are discussed.
\end{abstract}

\section{Résumé}

Une enquête a été menée auprès de 187 étudiants et étudiantes de l'Université Dalhousie visant à évaluer l'effet de la grève de trois semaines du corps

* Department of Education, Province of Nova Scotia

$\dagger$ Counselling and Psychological Services, Dalhousie University

$\Delta$ Halifax City School Board

This research was conducted while the first author was supported by a Lawson Foundation of Canada grant. The authors wish to thank David Mensink and Jeanette Hung for their assistance. 
professoral de l'Université Dalhousie en 1988 sur le travail académique, les émotions, et l'opinion qu'avaient les étudiants de l'Université. Les résultats furent désagrégés selon trois groupes d'étudiants soit ceux inscrits à la première année du premier cycle, les autres étudiants du premier cycle et les étudiants des cycles supérieurs et des programmes professionnels. Bien qu'on remarque une grande variabilité chez les répondants individuellement, on observe que généralement, la grève n'a eu que de faibles effets négatifs au plans académique et émotif, mais qu'elle a généré de vives réactions négatives quant aux opinions que les étudiants avaient de l'Université. Par rapport à la différenciation par groupes, les étudiants de la première année du premier cycle ont été davantage affecté au plan académique alors que ceux inscrits aux études supérieures ont manifesté le degré le plus élevé d'opinions négatives envers l'Université. Il n'y a toutefois pas de corrélation entre le niveau de perturbation académique personnellement rapporté par les étudiants et les opinions négatives détenues. Une seconde enquête effectuée deux ans plus tard démontre que les opinions des étudiants envers l'Université sont redevenues positives. L'article conclut sur une analyse des implication d'une grève du corps professoral.

University faculty strikes, indeed even the unionization of faculty, are relatively new phenomena in Canada. The trend for university faculty associations to become certified bargaining units began only about 15 years ago (Baxter, 1986; Bigelow, Gold \& Siren, 1987), and work stoppages by unionized faculty are an even more recent development.

The most salient effects of a faculty strike relate to the cessation of teaching and other direct educational services. Certainly, this is the aspect of a strike which is of most concern to students. However, although there have been some analyses of university strikes from the perspective of faculty and administrators (Fairbairn, 1988; Walsh, 1977), and some description of students' roles in negotiations (Aussieker 1976), the effects of a strike on students have not been well studied.

This may be because models of strike processes and effects originate outside the university system, and typically focus on economic factors (Lieberman \& Moskow, 1966; McCord, 1980; Sandver, 1987). For example, Sandver (1987) describes a strike as "...a tactical weapon in collective bargaining; it is a method of imposing the costs of disagreement on management or on the union." (p. 330). Thus the main considerations of strike strategy in the industrial sector may be reduced to calculations by the management of percentage of production disrupted, lost revenue and other strike costs, versus savings on wages and benefits; and calculations by the union of wages and union dues lost and strike 
benefits paid, versus wages and benefits gained (Sandver, 1987). Adapting an economic/industrial model of strikes for strikes within an educational system can involve substituting calculations of school days lost, minus days later made up, as measures of disruption of production (Lieberman \& Moskow, 1966). This manner of thinking about strikes can lead some educational administrators to conclude that a strike can be a good thing, such as one who told a teachers' union to "Go ahead, make my day" by striking, and indicated a strike length which would enable the school board to balance its budget (Sandver, 1987). Many educational administrators, particularly those at university, may consider measures like "days of school" as inappropriately concrete measures of education provided. However, trying to adapt industrial/economic concepts to strikes in an educational system may have more than just technical problems.

Fredman and Morris (1989) suggest that a fundamentally different model is needed for public sector strikes, including strikes in publically funded educational systems. This is because the very function of such strikes is inherently different. From the union perspective, the function of a public sector strike is not to cost the management money via lost production, but rather it is to bring third-party (especially "service recipient") pressure to bear on management. For management the problem with a public sector strike is the discontinuation of whatever function is supposed to be performed, along with pressure from third parties or their representatives (including politicians). For public school systems the prime third party of concern is the parents of the children. For universities it is the students themselves. Thus the pivotal consideration for university strikes is the effect on the students, as well as how they react.

This study was intended to initiate the development of knowledge about the effects on students. Such information will be of interest to both administrators and unionized faculty, as well as to university student service personnel planning how to help students cope academically and emotionally.

A retrospective survey of students was conducted following a faculty strike at Dalhousie University, a moderate-sized university of about 9000 full-time and 1000 part-time students. The strike occurred from November 4 to November 22 , 1988. Precise figures on how many faculty actually withdrew their services are not available. However, $80 \%$ voted to strike. The majority of faculty in most Faculties did not teach during the strike, and almost all students were affected to some degree. Librarians, instructors and professional counselors are also members of the bargaining unit and were on strike during that period. Moreover, the length of the time between the strike vote in September and the strike in November, and the prominence of pre-strike negotiations and planning, meant 
that the strike was preceded by a period of anticipation and rising tension. In addition the strike was followed by a period of uncertainty and increased workload for many students, related to the great variety of arrangements necessary within different classes, such as revision of course outlines, changes in assignments and due dates, making up missed material, and covering some material unusually quickly. The whole phenomenon may be best conceived as occurring throughout the Fall term in a sequence of three qualitatively different stages (before, during and after the work stoppage). The survey questionnaire thus was designed to gather comparable information about the academic and emotional effects of each of these three stages.

The student body at Dalhousie is heterogeneous, and there are many possibilities for relating students' characteristics to their reactions to a strike. Since from a student's perspective a faculty strike is primarily an "academic" event, the researchers decided to focus on how reactions to the strike varied with academic status. Respondents were divided into three groups for analysis: first year undergraduates, other year undergraduates, and graduate or professional school students. The division of undergraduate versus graduate/professional school students is a natural one, since their academic situations are quite different. There are also theoretical reasons for considering first year students separately. Perry's (1970) model of university student cognitive development posits that students typically start university with a tendency to view things in simpler true/false terms and with a tendency to believe that the authorities must know what is correct, characteristics which they lose with further university education. Additionally, it was hypothesized that first year undergraduates, new to the university system and generally more dependent on professors for guidance, would react differently to a faculty strike than students who had previous university experience.

Another issue of interest, aside from effects on students' work and emotions, is how the strike affected students' perceptions and opinions of the university. Ideally this type of assessment would be done on a longitudinal basis before a strike was expected as well as afterwards. Although this was not possible within this study, opinions about the university obtained in surveys of other students in other years were available for comparison.

\section{Method}

\section{Subjects}

Of the 200 students who agreed to complete the questionnaire and received a copy. 196 returned them, with 187 providing usable responses. Table 1 presents the academic characteristics of these 187 subjects. 


\section{Table 1}

Academic characteristics of subjects

\begin{tabular}{lcccccc} 
Registration Status & \multicolumn{5}{c}{ Year Level in Current Program } \\
\hline $\begin{array}{c}\text { Full-time } \\
183\end{array}$ & Part-Time & First & Second & Third & Fourth & Fifth \\
& 4 & 62 & 54 & 52 & 15 & 4 \\
Faculty & & & & & & \\
\hline Arts & Science & Education & $\begin{array}{c}\text { Health Professions } \\
\text { (undergraduate) }\end{array}$ & $\begin{array}{c}\text { or Dentistry } \\
\text { or Dedicine }\end{array}$ \\
32 & 60 & 4 & 19 & 28 & 21 \\
\hline
\end{tabular}

This information was used to group the students in the three a priori categories of First Year Undergraduates (FYU), with 38 members; Other Year Undergraduates (OYU), with 100 members; and Graduate or Professional School students (GPS), with 49 members. These 187 students comprised only about $2 \%$ of the total student population, and so of course the results based on their responses should be considered only suggestive.

As described in the procedure, immediate responses to a single item were sought and obtained from 31 other students; however, no descriptive information was obtained from such subjects other than that they were students at the university.

\section{Procedure}

In March 1989, students were approached at 20 different locations dispersed across campus, chosen as "informal" places (e.g., lounges, cafeterias) where students would be available to complete the questionnaire. Each location was designated as a place where 10 questionnaires could be collected from students in a particular Faculty or pair of Faculties. Students were informed about the purpose of the study, given assurance of anonymity, and then asked to fill out the questionnaire, which was collected immediately upon completion. Although refusal rates were not recorded, the surveyors (peer counselors and staff of the university Counselling Centre) reported that refusals were very rare. The positive response from students is attributed to the method of collection, in particular the personal contact between surveyor and student. Of 200 questionnaires distributed, 196 were collected, although only 187 were complete enough to permit an analysis. 
In addition, in November 1990 another 31 students were asked to complete only one item, which was the item asking students to rate their current overall impression of the university. Otherwise the same methodology was used (i.e., at the same sites on campus, voluntarily and anonymously).

\section{Questionnaire}

The questionnaire ${ }^{1}$ contained 27 items. Three concerned academic status (full-time vs. part-time; Faculty; year in program). One question asked about the extent of class interruption caused by the strike. Four questions were about the academic and emotional effects of the impending strike; five were concerned with the effects during the strike; and seven with effects after the strike. There were seven items pertaining to overall effects and opinions. In each of the latter four categories there was an open-ended question asking for relevant comments. For most of the other items a seven-point rating scale, ranging from "strongly positive" to "strongly negative," was provided. For example, one item asked "How did (anticipation of the impending strike) affect you emotionally?" and the points on the scale were "strongly positive," "moderately positive," "slightly positive," "no change," "slightly negative," "moderately negative" and "strongly negative." For the purposes of analysis, responses on such scales were assigned integers from 3 (strongly positive) to -3 (strongly negative).

\section{Results}

The results are discussed in terms of the three temporal phases ( pre-strike, strike, post-strike), as well as overall effects.

Pre-strike phase Seventy-five per cent of the respondents indicated that anticipation of the impending strike had some impact on them.

Table 2 presents the means and standard deviations, for each group, of their ratings of this effect on their academic work and on them emotionally. Although there was notable variability, on average the students indicated that there was only a "slightly negative" effect academically $(x=-0.7)$ and emotionally $(x=-0.9)$.

Analysis of variance ${ }^{2}$ indicated a significant between-group difference for effect on academic work $(\mathrm{F}=4.7, \mathrm{p}<.01)$, with posthoc paired comparisons indicating that the two undergraduate groups were significantly different from the graduate or professional school group, but not significantly different from each other. There were no significant differences between groups with respect to emotional effects $(F=1.7, p=.18)$. 
Table 2

Means and standard devations of ratings of academic and emotional effects of impending strike

Nature of Effect

\begin{tabular}{lcccc}
\hline \multicolumn{1}{c}{ Group } & \multicolumn{2}{c}{ Academic Work } & \multicolumn{2}{c}{ Emotional } \\
& $\mathrm{x}$ & $(\mathrm{SD})$ & $\mathrm{x}$ & $(\mathrm{SD})$ \\
\hline First year undergraduate & -1.0 & $(1.3)$ & -0.6 & $(1.8)$ \\
Other year undergraduate & -0.8 & $(1.4)$ & -1.1 & $(1.3)$ \\
Graduate/Professional school & -0.1 & $(1.5)$ & -0.9 & $(1.3)$ \\
Total & -0.7 & $(1.5)$ & -0.9 & $(1.4)$ \\
\hline
\end{tabular}

Note Possible range $=-3$ to 3

Strike Phase As a result of the continued teaching on the part of non-unionized (mainly part-time, plus medical and dental) faculty, as well as some unionized faculty, the specific extent of teaching interruption varied among students. Twenty-one percent had none of their courses continue during the strike; $46 \%$ had only one-fifth or less of their courses continue; and $69 \%$ had half or less than half of their courses continue; whereas only $10 \%$ had three-quarters or more of their courses continue and only $4 \%$ had all their courses continue. There were no significant differences among the three groups with respect to mean proportion of classes continuing (FYU 0.36, OYU 0.36, GPS 0.34 ; $F=0.1 p>.05$ ). Overall, while many students had some classes continue, most respondents experienced a disruption in most of their courses, and almost all were affected personally.

The mean number of courses that students continued to attend during the strike (1.4) was very similar to the mean number of their courses still being taught during the strike (1.7), indicating that the phenomenon of students not attending available courses to show support for the strike was quite small. Certainly the interruption of classes was something the students typically would have experienced as something being done to them, rather than something they chose.

Table 3 presents the means and standard deviations of ratings of academic and emotional effects during the strike. Overall, respondents indicated a "slightly negative" mean effect on academic productivity, although there was considerable variation among individuals. For example, only $21 \%$ of respondents actually indicated a "slightly negative" effect, and the ratings ranged from 
Table 3

Means and standard devations of ratings of academic and emotional effects during the strike

Nature of Effect

\begin{tabular}{lcccc}
\hline \multicolumn{1}{c}{ Group } & \multicolumn{2}{c}{ Academic Work } & \multicolumn{2}{c}{ Emotional } \\
& $\mathrm{x}$ & $(\mathrm{SD})$ & $\mathrm{x}$ & $(\mathrm{SD})$ \\
\hline First year undergraduate & -1.0 & $(1.8)$ & -0.3 & $(1.8)$ \\
Other year undergraduate & -1.2 & $(1.7)$ & -0.7 & $(1.4)$ \\
Graduate/Professional school & 0.3 & $(1.7)$ & -0.5 & $(1.4)$ \\
Total & -0.8 & $(1.8)$ & -0.6 & $(1.5)$ \\
\hline
\end{tabular}

"strongly positive" (6\% of respondents) to "strongly negative" (18\%). Examples had been provided with the rating scales to clarify their interpretation by respondents, with the example of a positive effect on academic work being "Used the time to catch up or get ahead," and the example of a negative effect being "Didn't do any work. Lost all motivation." Thus, it appears that although some students worked well on their own, most students reduced or ceased scholarly activity while classes were discontinued. There was a significant between-group effect for the means on this measure $(F=13.9, p<.001)$; with post hoc paired comparisons indicating that the two undergraduate groups were not significantly different from each other, but that each undergraduate group was more negative than the graduate or professional school group.

With respect to emotional effects, the mean rated effect was closest to the "slightly negative" point. This mean was reasonably representative, with $31 \%$ of respondents selecting that specific point, $23 \%$ indicating a moderately negative effect and $20 \%$ indicating no effect. There was no significant between-group effect $(F=1.4, p>.05)$.

Post-strike Phase After the strike was over, students experienced a variety of approaches to missed academic work: $85 \%$ of respondents indicated they were expected to "make up" at least some missed materiai; $72 \%$ were directed to "skip over" at least some missed material; and $54 \%$ were expected to attend extra classes. Seventy-five percent of respondents indicated that their workload was higher than normal following the strike.

Table 4 presents the means and standard deviations of the academic and emotional effects after the strike. The means for all groups show a slightly negative rating academically and a slightly positive rating emotionally. There were 
Table 4

Means and standard devations of ratings of post-strike academic and emotional effects

Nature of Effect

\begin{tabular}{lcccc}
\hline \multicolumn{1}{c}{ Group } & \multicolumn{2}{c}{ Academic Work } & \multicolumn{2}{c}{ Emotional } \\
& $\mathbf{x}$ & $(\mathrm{SD})$ & $\mathrm{x}$ & $(\mathrm{SD})$ \\
\hline First year undergraduate & -0.7 & $(1.6)$ & 0.2 & $(1.8)$ \\
Other year undergraduate & -0.7 & $(1.6)$ & 0.0 & $(1.6)$ \\
Graduate/Professional school & -0.2 & $(1.4)$ & 0.6 & $(1.5)$ \\
Total & -0.6 & $(1.6)$ & 0.2 & $(1.7)$ \\
\hline
\end{tabular}

no significant differences among groups with respect to academic effects $(\mathrm{F}=2.12, \mathrm{p}>.05)$ or emotional effects $(\mathrm{F}=2.30, \mathrm{p}>.05)$.

To explore the longer term effects of the strike, students also were asked if, at the time of the survey, the strike was having "a continuing impact on your level of productivity". A seven-point rating scale was provided for their responses. Four months after the strike, $69 \%$ of the respondents indicated there was no impact on their productivity; and $21 \%$ indicated there was a slight negative effect. The mean rating was -0.3 , with a standard deviation of 0.7 ; and there was no significant difference between groups $(F=0.38, p>.05)$.

\section{General effects}

It would be an error to infer from the above results concerning post-strike effects on the students that there were almost no continuing effects at all. Table 5 presents the students' ratings of how the strike affected their opinions of the listed groups. (The First Year Undergraduate, Other Year Undergraduate, and Graduate or Professional School groups did not differ significantly with respect to any of these ratings.) The most salient aspects of these results are the students' more negative opinions about the faculty in general (but not about their own professors), and the much more negative opinions about the administration. Fifty-five percent of the respondents had developed a more negative opinion about the faculty, and $87 \%$ had developed a more negative opinion about the administration.

Students also were asked to rate their overall opinion of the university. Specifically, they were asked: "Considering not just the strike, but your total experience at Dalhousie University, what is your current overall impression of 
Means and standard devations of ratings of changes in opinions about parts of the university

\begin{tabular}{|c|c|c|c|c|c|c|c|c|c|c|c|c|}
\hline \multirow{3}{*}{ Group } & & & \multicolumn{10}{|c|}{ Part of university } \\
\hline & \multicolumn{2}{|c|}{ Administration } & \multicolumn{2}{|c|}{ Faculty } & \multicolumn{2}{|c|}{$\begin{array}{c}\text { Own } \\
\text { Professors }\end{array}$} & \multicolumn{2}{|c|}{$\begin{array}{l}\text { Student } \\
\text { Union }\end{array}$} & \multicolumn{2}{|c|}{$\begin{array}{c}\text { General } \\
\text { Student } \\
\text { Body }\end{array}$} & \multicolumn{2}{|c|}{$\begin{array}{l}\text { Student } \\
\text { Services }\end{array}$} \\
\hline & $x$ & $(\mathrm{SD})$ & $\mathrm{x}$ & (SD) & $\mathrm{x}$ & (SD) & $x$ & (SD) & $\mathrm{x}$ & (SD) & $x$ & (SD) \\
\hline FYU & -1.6 & $(1.5)$ & -0.9 & (1.6) & -0.2 & $(1.2)$ & 0.1 & $(1.4)$ & 0.0 & $(0.7)$ & -0.2 & (1.0) \\
\hline OYU & -1.9 & (1.1) & -0.9 & (1.5) & -0.3 & (1.4) & -0.3 & (1.5) & -0.1 & (1.3) & -0.2 & (1.3) \\
\hline GPS & -1.6 & (1.3) & -0.3 & (1.7) & -0.1 & (1.4) & -0.4 & (1.3) & -0.2 & $(1.2)$ & -0.2 & $(0.0)$ \\
\hline Total & -1.8 & $(1.2)$ & -0.7 & (1.6) & -0.2 & (1.3) & -0.2 & $(1.4)$ & -0.1 & (1.2) & -0.1 & (1.2) \\
\hline$\underline{\text { Note }}$ & $\begin{array}{l}\text { FYU (F } \\
\text { OYU ( } \\
\text { GPS (G }\end{array}$ & $\begin{array}{l}\text { t year } \\
\text { ner year } \\
\text { duate/p }\end{array}$ & $\begin{array}{l}\text { dergra } \\
\text { nderg } \\
\text { fessio }\end{array}$ & $\begin{array}{l}\text { ate) } \\
\text { luate) } \\
\text { school) }\end{array}$ & & & & & & & & \\
\hline
\end{tabular}


Dalhousie?" Table 6 presents the results for this item. There was a significant between-groups effect $(\mathrm{F}=5.28, \mathrm{p}<.01)$; with post hoc paired comparisons indicating a significant difference between the FYU and the OYU groups. Overall $27 \%$ gave a positive rating to some degree and $57 \%$ gave a negative rating to some degree.

The ratings of the university following the strike contrast dramatically with ratings of the university obtained from students in previous surveys for other purposes. As part of a longitudinal study of attrition, Day, Murphy and Marriott (1987) surveyed a one-third random sample of students in all faculties during the first year of their program (October 1983) and during the second year of their program (March 1985). As part of a comprehensive questionnaire, such students were asked to rate their "overall opinion of Dalhousie" on a five-point scale. In October 1983, $85 \%$ of respondents gave a positive rating (63\% positive. $22 \%$ very positive) and only $8 \%$ gave a negative rating. In September $1984.79 \%$ gave a positive rating (67\% positive, $12 \%$ very positive) and only $7 \%$ gave a negative rating. Moreover, as part of another survey of students' opinions conducted by Christie (1988) in the Winter term of 1988, a sample of 872 undergraduate students rated their overall opinion of the university on a four-point scale (poor, satisfactory, good, excellent), with the ratings being 7\%, $40 \%, 48 \%$ and $5 \%$ respectively. Thus, despite the variations in wording of the items, there is a clear contrast between the rarity of negative ratings of the university prior to the strike and the high frequency of negative ratings after the strike (i.e., from 7 or $8 \%$ to $57 \%$ ).

As indicated in Table 6. however, the results with the same seven-point rating item in a survey of 31 students in November 1990 were much more positive

Table 6

Means and standard devations of ratings of overall impressions of the university

Group

$\mathrm{n}$

$\mathrm{x}$

SD

1989 survey

First year undergraduates

Other year undergraduates

Graduate/professional school

Total 
than the results obtained in $1989\left(x^{2}=36.7, p<.001\right)$. Indeed, $74 \%$ gave some degree of positive rating and only $13 \%$ gave some degree of negative rating. This recovery of positive opinions was subsequently confirmed in another survey (McKee. 1992), in which overall ratings by 760 undergraduate students in 1991 were: $6 \%$ poor, $37 \%$ satisfactory, $49 \%$ good, and $8 \%$ excellent. Such results are similar to the results obtained prior to the strike in 1984, 1985 and 1987.

\section{Correlational Analyses}

As a preliminary step in understanding the effects of a strike on students, post hoc correlational analyses were done to assess the degree to which some responses intercorrelated and may therefore be directly or indirectly related.

With respect to academic work and productivity, ratings of pre-strike effects correlated highly with ratings of strike period effects $(r=.61, p<.001)$; and each of these correlated with ratings of post-strike effects $(r=.38, \mathrm{p}<.001$; and $\mathrm{r}=.44, \mathrm{D}<.001$, respectively).

With respect to emotional effects, ratings of pre-strike effects correlated positively with strike period effects $(\mathrm{r}=.59, \mathrm{p}<.001)$; but ratings of pre-strike effects were slightly negatively correlated with post-strike effect ratings $(\mathrm{r}=-.14, \mathrm{D}<.05)$, and ratings of strike period effects were not correlated with ratings of post-strike effects $(r=.01, p>.05)$.

With respect to the relationship between academic and emotional effects, there was no significant correlation for the pre-strike period $(r=-.06, p>.05)$, only a slight correlation for the strike period $(\mathrm{r}=.19, \mathrm{p}<.01)$, and a strong correlation for the post-strike period $(r=.49, \mathrm{~g}<.001)$.

Thus pre-strike, strike period and post-strike effects on academic work and post-strike emotional effects are all intercorrelated, and are only weakly related or unrelated to the intercorrelated pair of pre-strike and strike period emotional reactions.

Interestingly, overall opinions of the university had little or no relationship to ratings of personally experienced effects. That is, overall opinions of the university correlated only slightly with rated effects on academic work during the strike $(r=.14, \mathrm{D}<.05)$ and emotional effects following the strike $(r=.15, \mathrm{p}<.05)$, and not with any other ratings of academic work or emotional effects, and not even with the proportions of students' classes which continued to be taught during the strike $(r=-.01, \mathrm{p}>.05)$. 


\section{Discussion}

The results not only demonstrate the negative effects of a faculty strike on students but also provide a suggestion for how these effects can be conceptualized and studied further.

One effect can be emotional distress, before and during a strike. There was notable variability amongst students with respect to the emotional effects they experienced, but interestingly the differences in emotional effects were not related to academic classification or even to the degree of academic disruption experienced. Perhaps future research in this area could benefit from analyses of individual differences, using the psychological concepts and instruments developed for understanding how different people cope with stress (e.g.. Compas, Forsythe \& Wagner 1988. Endler \& Parker 1990, Lazarus \& Folkman 1984), or even with natural disasters (e.g., Mangelsdorff 1985).

Another effect on students is disruption of their academic work, related not only to the temporary cessation of classes but also to an apparent disruption of their own productivity before, during and after a strike. The disruption was greater for undergraduate than graduate/professional school students. This difference may have been related to differences in their academic situations; that is, undergraduate students' work is more closely related to daily classes than is the work of graduate students; and some of the professional school students were less affected by the strike because of the non-unionized status of medical and dental faculty. It may be related as well to a higher capacity, opportunity and motivation for independent scholarly work amongst graduate and professional school students.

The third effect, a negative opinion about the university, was the largest in magnitude. Indeed it appears that there was a substantial shift, from students typically having positive overall opinions of the university, to many students having a negative overall opinion. Moreover, there is an interesting pattern to the changes in opinions: the largest specific effects were with respect to the university administration, and the next largest effects for the faculty in general, but there was not much effect with respect to students' own professors; there was no correlation between degree of negative opinion and the degree of academic disruption personally experienced by the individual; and the average magnitude of the effect on opinions appears larger than the average effects on academic work and emotions. Together these results suggest that negative overall impressions were not due to bitterness over personal suffering as much as negative judgments about what the strike revealed about the university. 
The larger negative judgmental effects for upper year undergraduates, as compared with first year undergraduates, is congruent with Perry's (1970) model of university student development in which first year students' belief in authorities swings to more skepticism with further university experience. The "in between" magnitude of effect in the case of graduate and professional school students is consistent with Perry's idea that eventually students can go on to a more complex view of the world. It should be noted that this study was not a direct test of Perry's model, and more explicit tests of it (e.g., Bateman \& Donald 1987) have revealed shortcomings. Nevertheless, at least the idea of grouping students by level of university experience to understand how they think, appears to be useful for understanding how they think about a university strike.

The recovery of positive opinions about the university two years later is heartening. This recovery may be related partly to natural changes in the student body. Two years later, many of the students at the university were not present for the strike. Moreover, the group with the most negative opinions, the undergraduates in upper years, was the most likely to have left. This illustrates how yearly changes in the composition of the student body makes its collective memory quite short.

However, the recovery of positive opinions may not have occurred simply because of the graduation of the disenchanted cohorts. The follow-up sample of opinions occurred after the next round of administration-faculty negotiations successfully concluded without a strike and in a more amiable manner.

It may be useful to consider what can be done to prevent the type of negative effects of a faculty strike identified in this study. If the emotional distress some students experience is not related closely to their academic disruption, then it is related presumably to their apprehension and interpretations about the situation. Clearly defined and explained procedures and contingency plans concerning what may happen and how students will be affected may help alleviate some unnecessary fears. Pre-strike agreements between administration and faculty concerning matters such as crossing picket lines, what will happen when classes resume, how class interruptions of various durations would be handled, etc., may help reduce emotional uncertainties. Indeed, joint explanation of such agreements might help maintain the impression that both sides care about students and will endeavour to minimize the effect of their disagreement on students. Counselling services should be available on campus to assist students who for various reasons may become especially anxious or depressed during a strike. (Through administration-union agreement, counselors continued to be 
available during the Dalhousie strike on a part-time basis to provide "essential services", and the services were well used.)

A large part of the academic disruption of a strike is unavoidable. Indeed academic disruption is the very idea. Nevertheless, many students may be able to reduce the effect on them by using their time during the cessation of classes to work independently or in cooperative groups (writing papers, reviewing previous material, reading ahead in textbooks, etc.). Some students do this; many do not. It may be beneficial for university counselling services to provide prestrike study skills workshops on how to use the time effectively. However, even well-organized students may cease work because of uncertainty about how the strike will affect subsequent content and requirements of their courses. Prestrike suggestions from faculty regarding priorities of course content and how best to use time during the strike would be helpful.

Some faculty may be reluctant to provide such pre-strike suggestions, out of fear of undermining the strike's effectiveness. However, such a stance may be a result of misconceiving a university strike as like an industrial strike, aimed at imposing costs on management by disrupting production as much as possible. If a university strike is reconceptualized on more of a public sector model, emphasizing the interplay of social and perhaps political pressures, then it becomes clear that the disruption of leaming per se is not the goal. Suggestions which facilitate some independent learning may help maintain positive student opinions about faculty, while still leaving the students with many reasons for wanting the strike to end (e.g., to get feedback, marks, credentials, etc.). Administrators have similar reasons to be helpful to students, although their relative lack of personal contact with most students puts them at a disadvantage.

In general, psychological research has often found that the negative effect of stressors on emotions and performance is worsened when the situation is unpredictable and uncontrollable (Cohen 1980). Thus, the guiding principles of ameliorating strike effects can be thought of as making arrangements and providing information to make the situation as predictable as possible and to help students achieve as much control as they can over their own academic work.

The more negative evaluations of the university as a result of a strike are to some degree inevitable. There may be, however, ways of ameliorating this effect as well. During labour disputes it is traditional for both sides to engage in negative public characterizations of the other side's behaviour and demands (McCord. 1980). The protagonists may well understand this approach as just a type of strategy. Students, however, may be influenced by such public statements, and come to a lower opinion of the administration, faculty or university 
in general. Just as negotiators often work out some ground rules for the negotiating process, and sometimes even agree to refrain from public statements during certain crucial phases, it might be possible to agree that statements to students and the public will be focused on the positive merits of one's own position and not on negative characterizations of the other side.

This would be consistent with the "Queensbury Rules" approach to public sector strikes advocated by Morris (1986). That is, both sides agree beforehand to follow certain rules of conduct during a conflict, especially with respect to effects on third parties. These agreements could include guidelines to refrain from strategies that would unnecessarily aggravate student distress or damage the university's public image.

There are legal restrictions in each province conceming strikes and conduct during strikes. For the Dalhousie strike, the relevant provincial laws were the Trade Union Act (1982) and the Labour Standards Code and Regulations (1989). The suggestions contained in this paper are compatible with those laws; residents in other provinces may wish to check their relevant legislation. However, except when they ban strikes in essential services, laws concerning strikes typically focus on the conduct of the protagonists towards each other and are not concerned with indirect effects on third parties (Sandver, 1987). Thus, focusing on what is legally permissible will not provide sufficient guidance. It is, of course, legally possible for the parties involved to agree on further restrictions on their behaviour with respect to students. Such agreement probably will be more likely if it is arranged before a strike occurs.

Future research on the effects of strikes on students would be aided by more longitudinal analyses, including pre- and post-strike assessments, along with assessment of the effectiveness of measures to alleviate negative effects. There may be situations where an impending strike is sufficiently predictable to permit such research. Moreover, considering that this study indicated some pre-strike negative effects, even study of "near-strikes" would be useful. Research in this area may not only increase understanding of strike and near-strike effects, but also stimulate further efforts at reducing the effects on students.

\section{Notes}

${ }^{1}$ Copies of the questionnaire are available from the authors upon request.

2 Analysis of variance was used for between-group comparisons, especially because it enables simpler presentation of results and differences in terms of means and standard deviations. However, in this instance, and in seven of the nine significant differences discussed, the differences were also significant using the more conservative Chi-square tests. 


\section{References}

Aussieker, B. (1976). Students and bargaining at public and private colleges. Monthly Labour Review, 99, 31-33.

Bateman, D. \& Donald. J. (1987). Measuring the intellectual development of college students: Testing a theoretical framework. The Canadian Journal of Higher Education, 17, 27-45.

Baxter, H. (1986). CAUT's role in university collective bargaining. CAUT Bulletin, 33, 9-10.

Bigelow, C., Gold, S., \& Siren, P. (1987). Report of the CAUT External Review Committee. CAUT Bulletin. 34, 5-14.

Christie. B. (1988). Student views of their undergraduate experience at Dalhousie. Halifax: Dalhousie University, Analysis and Planning Department.

Cohen. S. (1980). Aftereffects of stress on human performance and behaviour: A review of research and theory. Psychological Bulletin, 88, 82-108.

Compas, B., Forsythe, C., \& Wagner, B. (1988). Consistency and variability in causal attributions and coping with stress. Cognitive Therapy and Research, 12, 305-315.

Day, V., Marriott, E., \& Murphy, H. (1986, June). Factors influencing students' decisions to persist or withdraw from university programs. Paper presented at the meeting of the Canadian Society for the Study of Education, Winnipeg, Manitoba.

Endler, N. S., \& Parker, J. D. (1990). Multidimensional assessment of coping: A critical evaluation. Journal of Personality and Social Psychology, 58, 844-854.

Fairbairn, B. (1988). The prof motive: Radical conservatism at the University of Saskatchewan. Newest Review, 14, 20-23.

Fredman, S., \& Morris, G.S. (1989). The State as employer: Labour law in the public services. London: Mansell Pub. Co.

Labour Standards Code and Regulations. (1989). Halifax: Queen's Printer, Province of Nova Scotia.

Lazarus, R.S., \& Folkman. S. (1984). Stress, appraisal and coping. New York: Springer Publishing Co.

Lieberman, M., \& Moskow, M. (1966). Collective negotiations for teachers. Chicago: Rand McNally.

Mangelsdorff, A.D. (1985). Lessons learned and forgotten: The need for prevention and mental health interventions in disaster preparedness. Journal of Community Psychology, 13, 239-252.

McCord. N. (1980). Strikes. New York: St. Martin's Press.

McKee, E.A. (1992). 1991 Undergraduate Survey. Halifax: Dalhousie University, Student Services.

Morris, G.S. (1986). Strikes in Essential Services. London: Mansell Publishing Co.

Perry, W.G. (1970). Forms of intellectual and ethical development in the college years: A scheme. New York: Holt, Rinehart and Winston.

Sandver, M.H. (1987). Labor relations: Process and outcomes. Toronto: Little, Brown and Co.

Trade Union Act (1982). Halifax: Queen's Printer, Province of Nova Scotia. 
Walsh, J. (1977). Stevens institute of technology: After the strike, still unsettled. Science, 196, 280-283.

Webb, L.D., Green, J.T., Montello, P.A., \& Norton, M.S. (1987). Personnel administration in education. Columbus: Merrill Publishing Co. 